О. В. Удова, Л. А. Кананчук. Формирование готовности педагогов к воспитанию коллективизма у детей дошкольного возраста

Научная статья

УДК 378.162.32

DOI: $10.18101 / 2307-3330-2021-4-87-91$

\title{
ФОРМИРОВАНИЕ ГОТОВНОСТИ ПЕДАГОГОВ К ВОСПИТАНИЮ КОЛЛЕКТИВИЗМА У ДЕТЕЙ ДОШКОЛЬНОГО ВОЗРАСТА
}

\section{(с) Удова Ольга Владимировна}

кандидат психологических наук, доцент, Иркутский государственный университет Россия, 664003, г. Иркутск, ул. Карла Маркса, 1 udovao@yandex.ru

\section{(C) Кананчук Лидия Александровна}

кандидат психологических наук, доцент, Иркутский государственный университет Росссия, 664003, г. Иркутск, ул. Карла Маркса, 1 kananchuk.la@yandex.ru

Аннотация. Статья посвящена готовности педагога к воспитанию коллективизма у детей дошкольного возраста. Описано влияние педагога как одного из необходимых психолого-педагогических условий формирования коллективизма у детей дошкольного возраста. Представлены результаты исследования когнитивного, деятельностного и эмоционального компонентов готовности педагогов к воспитанию коллективизма у дошкольников. С педагогами были проведены дискуссия «Коллективизм или индивидуализация», семинар-практикум «Готовы вы ли вы к развитию коллективизма», тренинг «Воспитание коллективизма у детей старшего дошкольного возраста» (4 встречи-занятия), семинар-практикум «Способы организации групповой деятельности с детьми дошкольного возраста», творческий час «Традиции группы как одно из средств коллективизма детей старшего дошкольного возраста», семинарпрактикум «Коллективно-творческие дела как средство развития коллективизма у детей дошкольного возраста».

Представлено методическое сопровождение, направленное на формирование готовности педагогов к воспитанию коллективизма.

Ключевые слова: коллективизм, воспитание коллективизма, психолого-педагогические условия воспитания коллективизма, готовность педагога к воспитанию коллективизма.

\section{Для цитирования}

Удова О. В., Кананчук Л. А. Формирование готовности педагогов к воспитанию коллективизма у детей дошкольного возраста // Вестник Бурятского государственного университета. Образование. Личность. Общество. 2021. № 4. С. 87-91.

ФГОС ДО постулирует в современном образовании индивидуализированный подход. Вместе с тем, важна и социализация, так как осуществляется подготовка детей не столько к обучению в школе, сколько к жизни в целом. Следующая ступень системы образования, где ведущей деятельностью является учебная, требует от школьника овладения совместными действиями, а задания в парах - еще и взаимодействия. Ребенок, как и взрослый, большую часть времени проводит в 
обществе, коллективе, поэтому умение строить взаимоотношения со сверстниками - залог будущей успешной жизни.

Исследованиями ряда авторов $[2 ; 3 ; 4 ; 5 ; 6 ; 7]$ установлено, что коллективизм характеризуется взаимопомощью, отзывчивостью, дружбой, ответственностью, добротой, инициативой, сопереживанием, честностью, чувством солидарности с группой, осознанием себя ее частью, готовностью к действиям в пользу группы и общества, единством цели, деятельности, умением и привычкой сообща ставить общественно полезные цели своего труда, тем, насколько социальное, общественное прониклось личным, индивидуальным интересом.

А. С. Козлова и Т. А. Куликова утверждают, что коллективизм - это сложное интегральное качество, которое, безусловно, в полной мере может быть присуще лишь взрослому человеку. Для детей 3-6 лет правильнее говорить, по мнению вышеупомянутых авторов, о воспитании коллективных взаимоотношений, т.е. взаимоотношений, которые характеризуются взаимопомощью, отзывчивостью, дружбой, ответственностью, добротой, инициативой [6]. Я. Л. Коломинский и Л. В. Артемова считают, что условием для воспитания таких взаимоотношений будет служить общение детей с другими людьми, как с взрослыми, так и со сверстниками. Именно общение помогает получить какую-либо информацию, а также получить опыт взаимодействия, сопереживания, взаимовлияния [2].

Кроме того, коллективизм определяется как чувство солидарности с группой, осознание себя ее частью, готовность к действиям в пользу группы и общества [3].

Таким образом, коллективизм - нравственное качество, которое проявляется в чувстве товарищества, принадлежности к коллективу, обязанности перед ним, умении при необходимости подчинять личные интересы общественным.

Успешному развитию того или иного навыка, качества у детей дошкольного возраста содействуют взрослые. В воспитании коллективизма важна роль воспитателя [1]. Поэтому мы определили степень готовности педагогов детского сада к воспитанию коллективизма у дошкольников. Мы применили опросник для педагогов, позволяющий выявить их отношение к данному качеству, способность и возможности для его развития. А также проанализировали календарно-тематические планы на предмет планирования совместной деятельности с интересующей нас целью и осуществили наблюдение за деятельностью педагогов.

Представим полученные в процессе опроса данные о готовности педагогов к развитию коллективизма детей по каждому компоненту. К среднему уровню когнитивного компонента развития коллективизма у детей было отнесено 7 $(43,75 \%)$ педагогов. Эти педагоги имеют представление о развитии коллективизма у дошкольников: дают точное или примерное определение понятию «коллективизм», знают, какие качества необходимо воспитывать в детях для развития коллективизма и как они проявляются, но не все могут перечислить средства и технологии развития коллективизма, либо перечисляют некоторые.

Повышенный уровень когнитивного компонента готовности к развитию коллективизма был выявлен у $9(56,25 \%)$ педагогов. Педагоги, отнесенные к этому уровню, знают, что такое коллективизм и владеют другими теоретическими знаниями в этой области, а также определяют психолого-педагогические условия развития коллективизма. 
О. В. Удова, Л. А. Кананчук. Формирование готовности педагогов к воспитанию коллективизма у детей дошкольного возраста

На среднем (базовом) уровне деятельностного компонента находится большинство педагогов - 12 (75\%). Эти педагоги проводят работу по развитию коллективизма в своих группах, но у них нет определенной системы. Они предлагают ту деятельность, которую реализует каждый воспитатель, не организуя четкой работы для своей группы или какие-нибудь отличительных вариантов использования различных технологий для развития коллективизма.

На высоком уровне деятельностного компонента выявлено 4 (25\%) педагогов, которые организуют работу в своей группе по развитию коллективизма, ведут системную работу, что можно увидеть в календарно-тематическом плане. Педагоги ставят конкретные цели и знают, какого результата хотят добиться в развитии коллективизма.

12 (75\%) педагогов, отнесенных к среднему уровню эмоционального компонента готовности к развитию коллективизма, заинтересованы в развитии данного качества у детей своей группы, но не придают этому большого значения. Например, Ирина 3. и Ирина Л. (педагогический стаж 4 года) считают, что коллективизм важен для облегчения работы воспитателя, чтобы дети были организованы и дружны.

На высоком уровне эмоционального компонента готовности педагогов к развитию коллективизма находится $2(12,5 \%)$ воспитателей. Педагоги заинтересованы в развитии коллективизма у детей и стараются ежедневно заниматься воспитанием данного качества.

Низкий уровень эмоционального компонента выявлен у 2 (12,5\%) педагогов, которые не заинтересованы в развитии коллективизма у детей и не уделяют этому времени в своей работе. Из беседы с этими педагогами мы выяснили, что они считают воспитание коллективизма бессмысленным занятием, когда в группе очень высокая посещаемость.

То есть, наименее сформированным является эмоциональный компонент, связанный с отношением педагогов к воспитанию коллективизма у детей дошкольного возраста и желанием действовать в этом направлении. Наиболее сформированным является когнитивный компонент - наличие представлений о процессе и технологиях развития коллективистических чувств у дошкольников. Однако, применение знаний в профессиональной деятельности осуществляется периодически.

Следовательно, необходимо создавать условия для заинтересованности в воспитании коллективизма, обогащение опыта профессиональной деятельности содержанием организации психолого-педагогических условий для развития данного качества. С педагогами были проведены: дискуссия «Коллективизм или индивидуализация», семинар-практикум «Готовы вы ли вы к развитию коллективизма», тренинг «Воспитание коллективизма у детей старшего дошкольного возраста» (4 встречи-занятия), семинар-практикум «Способы организации групповой деятельности с детьми дошкольного возраста», творческий час «Традиции группы как одно из средств коллективизма детей старшего дошкольного возраста», семинар-практикум «Коллективно-творческие дела как средство развития коллективизма у детей дошкольного возраста». 
В процессе методического сопровождения педагогов обсуждались темы, связанные с разграничением понятий «коллективизм» и «индивидуализм». Рассуждали, как в условиях требований ФГОС ДО к осуществлению индивидуализации образования, совместить и воспитание коллективистических черт характера у детей. Педагоги владели некоторыми теоретическими аспектами в данном вопросе, активно включались в обсуждение. В результате пришли к выводу, что процессы коллективизации и индивидуализации связаны между собой. Пришли к мнению, которое все поддержали, что коллективизм будет развиваться тогда, когда будет развиваться каждая личность. В процессе тренинга «Готовы ли вы к развитию коллективизма» педагоги осознали, что педагогический коллектив должен был сплоченным, чтобы показывать пример детям, а также у педагогов должно быть стремление, интерес к воспитанию коллективизма в своей группе и ДОУ в целом. В процессе семинара «Воспитание коллективизма у детей старшего дошкольного возраста» педагоги обогатили свои знания об условиях, которые необходимо создавать в группе для воспитания коллективизма. Многие сделали вывод, что нужна серьезная подготовка и в их группах созданы не все условия, которые необходимы. Были раскрыты проблемы, которые возникают при воспитании коллективизма у детей дошкольного возраста. Большинство участников семинара согласились с тем, что данная работа должна начинаться как можно раньше, с простых элементов. Особое внимание решили обращать на взаимоотношения со сверстниками, позитивный психологический климат в группе. Педагоги узнали о новых способах организации группой деятельности с детьми дошкольного возраста, либо актуализировали свои знания. Некоторые педагоги поделились своим опытом. Например, рассказали о таких формах совместной деятельности с детьми, как коллективные творческие дела, традиции группы, коллективная, групповая деятельность, журнал группы. Педагоги познакомились с различными способами организации подгрупп детей. То есть, пришли к выводу, что стараются развивать коллектив в своих группах, но, по их мнению, нужно еще продолжить работу в этом направлении.

Полученные в результате сравнения данные свидетельствуют, что проведенная нами работа была эффективной, способствовала развитию когнитивного, деятельностного и эмоционального компонентов готовности педагогов к воспитанию коллективизма в группе сверстников. Благодаря проведенным мероприятиям педагоги углубились в сущность коллективизма, осознали его важность, познакомились с методами, средствами, формами, технологиями развития коллективизма детей 6-7 лет и готовы использовать их в своей работе.

Литература

1. Абатурова Е. И., Удова О. В. Воспитание у дошкольников чувства коллективизма в условиях индивидуализации образования // Вестник Иркутского университета. 2020. № 23. С. 154-155. Текст: непосредственный.

2. Воспитание дошкольника в семье: вопросы теории и методики / под редакцией Т. А. Марковой. Москва: Педагогика, 2019. 191 с. Текст: непосредственный.

3. Дмитриева А. В. Педагогический аспект влияния социально-культурной анимации на воспитание коллективизма у детей и подростков // Научный журнал КубГАУ. 2016. № 115(1). С. 70-88. Текст: непосредственный.

4. Дубинина А. И. Воспитание доброты // Вопросы науки и образования. 2018. № 17. С. 67-70. Текст: непосредственный. 
О. В. Удова, Л. А. Кананчук. Формирование готовности педагогов к воспитанию коллективизма у детей дошкольного возраста

5. Зотова И. В., Умерова М. С. Особенности межличностных взаимоотношений детей старшего дошкольного возраста // Наука, техника и образование. 2017. № 5. С. 57-60. Текст: непосредственный.

6. Козлова С. А. Дошкольная педагогика: учебник для студентов среднего профессионального учебного заведения. 11-е изд. Москва: Академия, 2012. 416 с. Текст: непосредственный.

7. Макаренко А. С. О воспитании. Москва: Политиздат, 2013. 256 с. Текст: непосредственный.

Статья поступила в редакичию 02.10.2021; одобрена после рецензирования 13.10.2021; принята к публикаџии 15.12.2021.

\title{
THE FORMATION OF TEACHERS' READINESS FOR THE RAISING OF COLLECTIVISTIC TRAITS OF PRESCHOOL CHILDREN
}

\author{
Olga $V$. dova \\ Candidate of Psychological Sciences, Associate Professor \\ Irkutsk State University \\ 1 Karl Marx St., Irkutsk, 664003 Russia \\ udovao@yandex.ru \\ Lidia A. Kananchuk \\ Candidate of Psychological Sciences, Associate Professor \\ Irkutsk State University \\ 1 Karl Marx St., Iikutsk, 664003 Russia \\ kananchuk.la@yandex.ru
}

The article is devoted to the readiness of a teacher to raise collectivism in children of preschool age. The influence of a teacher is described as one of the necessary psychological and pedagogical conditions for collectivism in children of preschool age. The results of the study of the cognitive, active and emotional components of the readiness of teachers to raise collectivism in preschoolers are presented. A variety of events with teachers were held: the discussion «Collectivity or Individualization», the workshop «Are we ready for the development of collectivism», training «Raising of collectivism of senior preschool children» (4 practical classes), workshop «Methods of organizing group activities with children of preschool age», creative workshop "The group's traditions as one of the collectivism of senior preschool children», seminar "Collective and creative activities as a means of developing collectivism of preschool children.

Methodical support is presented to form the readiness of teachers to raise collectivism.

Keywords: collectivism, collectivism raising, psychological and pedagogical conditions of collectivism raising, teacher's readiness for collectivism raising.

The article was submitted 02.10.2021; approved after reviewing 13.10.2021; accepted for publication 15.12.2021. 